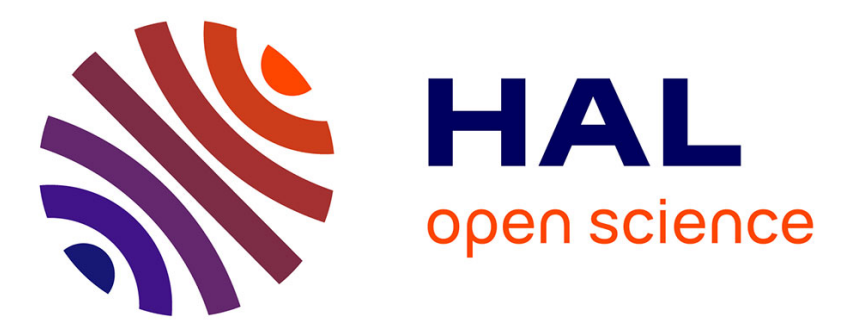

\title{
Trading Forward: The Paris Bourse in the Nineteenth Century
}

Paul Lagneau-Ymonet, Angelo Riva

\section{To cite this version:}

Paul Lagneau-Ymonet, Angelo Riva. Trading Forward: The Paris Bourse in the Nineteenth Century. 2019. halshs-01984911

\author{
HAL Id: halshs-01984911 \\ https://shs.hal.science/halshs-01984911 \\ Preprint submitted on 17 Jan 2019
}

HAL is a multi-disciplinary open access archive for the deposit and dissemination of scientific research documents, whether they are published or not. The documents may come from teaching and research institutions in France or abroad, or from public or private research centers.
L'archive ouverte pluridisciplinaire HAL, est destinée au dépôt et à la diffusion de documents scientifiques de niveau recherche, publiés ou non, émanant des établissements d'enseignement et de recherche français ou étrangers, des laboratoires publics ou privés.

\section{(1)(1) $\$(0)$}

Distributed under a Creative Commons Attribution - NonCommercial - ShareAlikel 4.0 

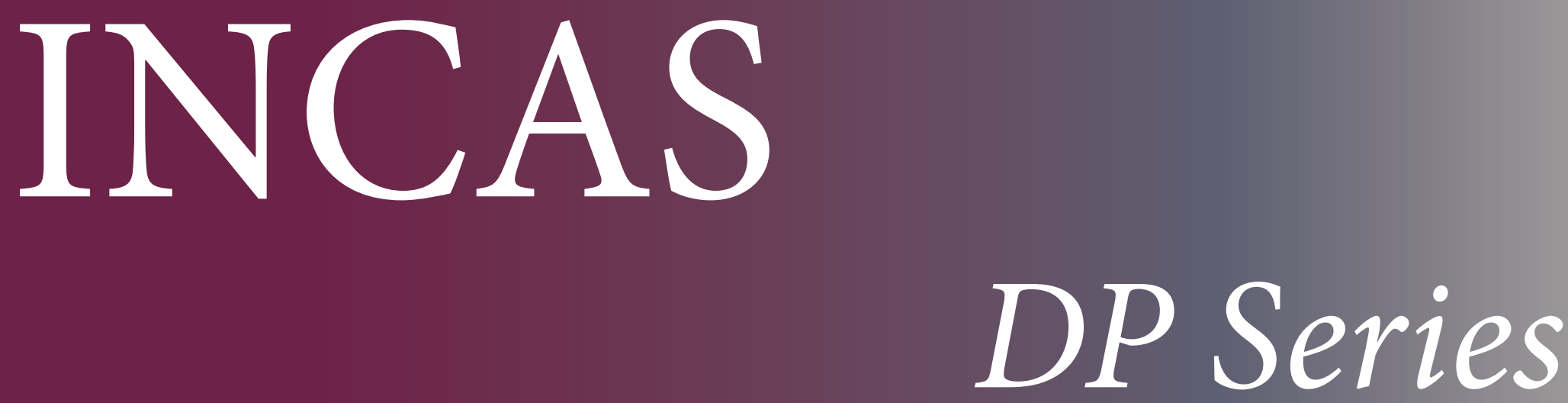

\title{
Discussion Paper Series 2019 \#01
}

\section{Trading forward: the Paris Bourse in the nineteenth century}

\author{
January 2019
}

Paul Lagneau-Ymonet

Paris Dauphine, PSL Research University, IRISSO

Angelo Riva (corresponding author)

European Business School - Paris and Paris School of Economics

This work has received funding from the European Union's Horizon 2020 research and innovation programme under the Marie Skłodowska-Curie grant agreement No 645763.

IN C A S

Understanding institutional change in Asia: a comparative perspective with Europe

http://incas.hypotheses.org/

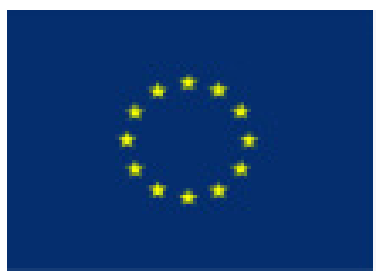




\section{ABOUT THE INCAS PROJECT}

INCAS is a Marie Skłodowska-Curie Actions R.I.S.E funded project under the European Commission's H2020 Programme.

The project INCAS aims at creating a top-level research and advanced training network on institutional change in Asia, in comparative perspective with Europe.

The coordinator, Ecole des Hautes Etudes en Sciences Sociales (France), promotes this network together with Oxford University (UK), Freie Universität Berlin (Germany), and in collaboration with Waseda University (Japan). The aim of the proposed mobility scheme is to give birth to a European consortium and network of faculties and advanced graduate students specialized in the comparative analysis of institutional change in Asia and Europe. The partners have chosen Japan as a reference point because of its comparability with Europe as shown by previous studies, its historical influence on development and further institutional changes in Asia, and the expertise accumulated within our research team.

Analyzing current economic dynamics in Japan and later expanding this analysis to other Asian countries promises to generate insights that might be help to better understand challenges for Europe and to prepare relevant policy proposals. Our purpose is to compare the results obtained in the case of Japan and few other Asian countries (South Korea, Taiwan, China, and possibly Thailand, after having checked the data availability), not only to previous results on Europe but also to original results we will get on European countries (primarily France - which will be our reference country in Europe - and then the UK, Germany, and Italy) in mobilizing new historical data and applying our theoretical framework. 


\title{
Trading forward: the Paris Bourse in the nineteenth century
}

\author{
January 2019 \\ Paul Lagneau-Ymonet \\ Paris Dauphine, PSL Research University, IRISSO \\ Angelo Riva (corresponding author) \\ European Business School - Paris and Paris School of Economics
}

\begin{abstract}
Contrary to what law and finance theory would predict, the Paris Bourse was highly liquid at the turn of the 20th century: the traded volumes amounted to four times the French GDP. This magnitude was mainly due to forward trading. The Bourse had developed as a forward market, despite a ban on forward transactions. The official stockbrokers played a key role in legitimizing and legalizing these operations, previously equated with gambling. The 1885 legalizing act initiated a new field of law and made possible further regulatory changes that paved the way for the heyday of the Paris Bourse.
\end{abstract}

\section{Keywords}

Financial markets; Legal origin; Nineteenth century; Traded volumes, France

\section{Acknowledgment}

Corresponding author: Angelo Riva (European Business School - Paris and Paris School of Economics)

E-mail: angeloriva@ebs-paris.com 


\section{Introduction}

'Law and Finance' theory considers that civil-law countries have lower financial development than common-law countries, because of their weaker legal protection of corporate shareholders and creditors. Consequently, firms in civil-law countries have restricted access to external finance. This harms their performances and reinforces ownership concentration. ${ }^{1}$ At the macro level, it contributes to lower economic growth. ${ }^{2}$ Among civil-law countries, France scores poorly, because of the slower adaptation of its institutions to changing economic and business needs. ${ }^{3}$

Not only do critics of the 'Law and Finance' approach highlight its ahistorical character, they also contest its main argument. In a recent special issue of this journal, the guest editors concluded that 'business history suggests that legal origins do not matter'4 and formulated an ambitious research agenda. They called for research on the early development of stock markets in European civil-law economies, in order to document interactions between regulators and regulated as well as actual business practices, beyond formal rules. According to the finance and growth literature ${ }^{5}$ and historical studies on financial development, ${ }^{6}$ liquidity is more important than listing or market capitalization for economic growth: the higher the liquidity, the lower the risk premium that investors demand, and hence the lower the cost of capital for issuers and the higher the investment. Even though 'overtrading' is also crucial in the occurrence of manias, panics, and crashes, ${ }^{7}$ scholars have often neglected trading volumes ${ }^{8}$ because of the difficulties in putting together historical series.

Drawing on newly-available archival records, ${ }^{9}$ we contribute to the 'Law and Finance' debate by documenting a striking counter-example: the early development of the Paris Bourse, second only to London before the First World War. We provide original estimates of the traded volumes at the Paris Bourse at the turn of the 20th century. These volumes amounted to four times the French GDP. This magnitude was mainly due to forward trading, which was three times the size of GDP (counted on both sides). ${ }^{10}$ Since its creation in 1724 , the Bourse had been primarily a forward market, despite a ban on such operations until their legalization in 1885. We also document the key role played by the official Paris stockbrokers in the process that led from the legitimation to the legalization of forward operations that had long been equated with gambling. To do so, we bring to light the formal and informal rules and the actual practices through which forward contracts were negotiated. We then explain the disputed adaptation of these rules and practices to business needs and regulators' expectations by analyzing the organization of the Bourse and the guild running it, its rivalries with other financial intermediaries, and the dynamic power plays with judges and the government. By seeking to organize the fair ordering of trading through social control, institutional innovations, and legal strategies, the official stockbrokers built the legitimacy of forward operations and eventually obtained their full legal recognition.

The process was disputed and non-linear. Nevertheless, the 1885 Act made possible the creation a new field of law - securities law (droit boursier) - that had been hindered by the controversies on forward operations. The first securities law passed in 1890 allowed further regulatory changes that culminated in the 1898 reform of the Paris financial center. This reform enhanced the transparency of financial transactions and supported the development of the number of listed securities. The reform also stabilized the Bourse by effectively dealing with counterparty risk and significantly decreased transaction costs. ${ }^{11}$ Consequently, traded volumes as a ratio of GDP reached heights similar to the 2006 level.

The rest of the paper is structured as follows. The next section addresses the question of financial liquidity and stability in the specific context of the Paris Bourse and provides original estimates of traded volumes. Section 3 describes the legislation on forward operations and stockbrokers; it relates the pivotal role of the jurisprudence. The fourth section analyzes the stockbrokers' strategies to cope with the threats incurred by legal uncertainties. They raised their social status, strengthened the reliability of the organization of the Bourse and developed actions to shape the jurisprudence. Section five focuses on the 1885 law that legalized forward operations. The final section concludes. 


\section{Liquidity and Stability}

At the end of the $19^{\text {th }}$ century, the tension between stability and liquidity of stock markets was the subject of intense debate in Europe. ${ }^{12}$ Although liquidity was already considered a crucial quality of stock markets, frequent financial crises affected both the financing of the economy and personal wealth. In France, the debate focused on the legal status of forward operations. They were performed without deposit of securities and money and most of the transactions were settled by the payment of the difference between the transaction prices and the repurchase prices, with no actual delivery of the securities. ${ }^{13}$

Although they were the most common instruments for trading since the foundation of the Paris Bourse in 1724, forward operations were equated with gambling. Legislators refused to recognize them, but without forgoing their contribution to the development of the market, and more specifically to the issuance of public debt. This ambiguity is the main reason why judicial authorities did not strictly uphold forward operations, before their full legal recognition in 1885. Clients could therefore trade with no risk and endanger the solvency of their brokers: if they won, they cashed in; when they lost, they could refuse to pay. This amplified the systemic risk, as exemplified in 1882 by the collapse of the Lyon Bourse (the second largest French exchange) and the bail-out of the Paris Bourse. ${ }^{14}$ Defaulting clients could be kicked out of the Bourse by the official brokers, but a thriving over-the-counter (OTC) market in Paris as well as six regional exchanges in the country mitigated this threat. This pressure from rival intermediaries, fueled by the push for a greater market depth by large market participants, combined with the greed of the official stockbrokers to explain the role they played in manias, panics, and crashes throughout the century.

According to Banner, ${ }^{15}$ at the very beginning of the $19^{\text {th }}$ century, forward trading exceeded the volume of cash transactions by a factor of 10 . In the 1830 s, the ratio was 1 to $50 .{ }^{16}$ Fresh archival records provide more accurate estimates for the end of the century. Fig. 1 compares two series: the volumes of spot transactions handled by the clearing house of the Bourse, and the volumes of forward transactions settled through the actual delivery of securities. Available archival data for 1906 gives us an insight into the magnitude of the phenomenon captured by these series. ${ }^{17}$ Only $11 \%$ of the forward volumes ended with the actual delivery of securities; that same year, around $80 \%$ of the spot transactions were recorded by the clearing house. These data confirm secondary sources indicating that forward operations settled through the actual delivery of securities were residual. 
Fig. 1 Cleared spot transactions and settled forward transactions at the Paris Bourse, 1872-1912

(in billions of current francs)

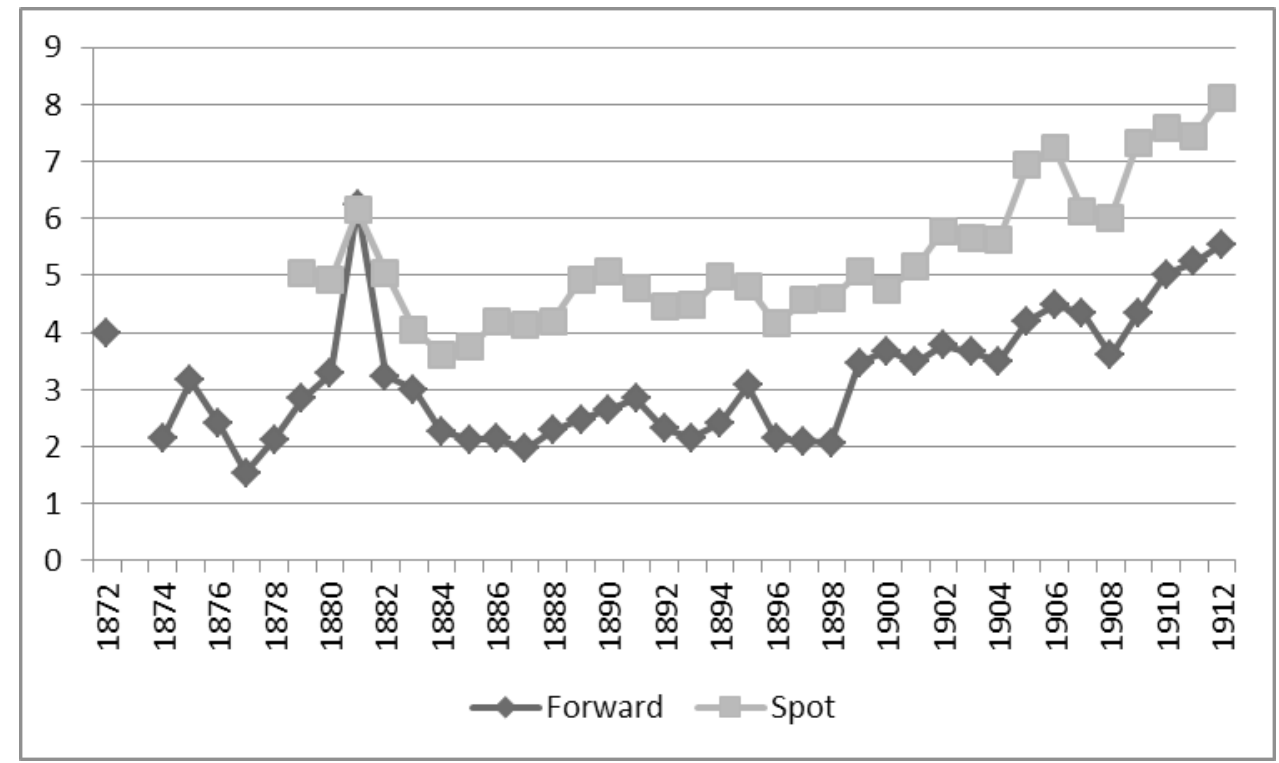

Source: see Data Appendix

Nevertheless, delivered forward-traded securities multiplied by four between 1877 and 1881 . Under the assumption that these proportions did not vary from the 1870 s to the dawn of the $20^{\text {th }}$ century, forward-traded volumes in 1881 amounted to five times the French GDP. After the $1882 \mathrm{crash}$, volumes stagnated until 1887. Then they followed an upward trend until the First World War. Spot transactions followed a similar trend, although they only accounted for $0.7 \%$ of the GDP in 1881 .

Fig. 2 Traded volumes in Paris (as a ratio of French GDP, transactions counted on both sides)

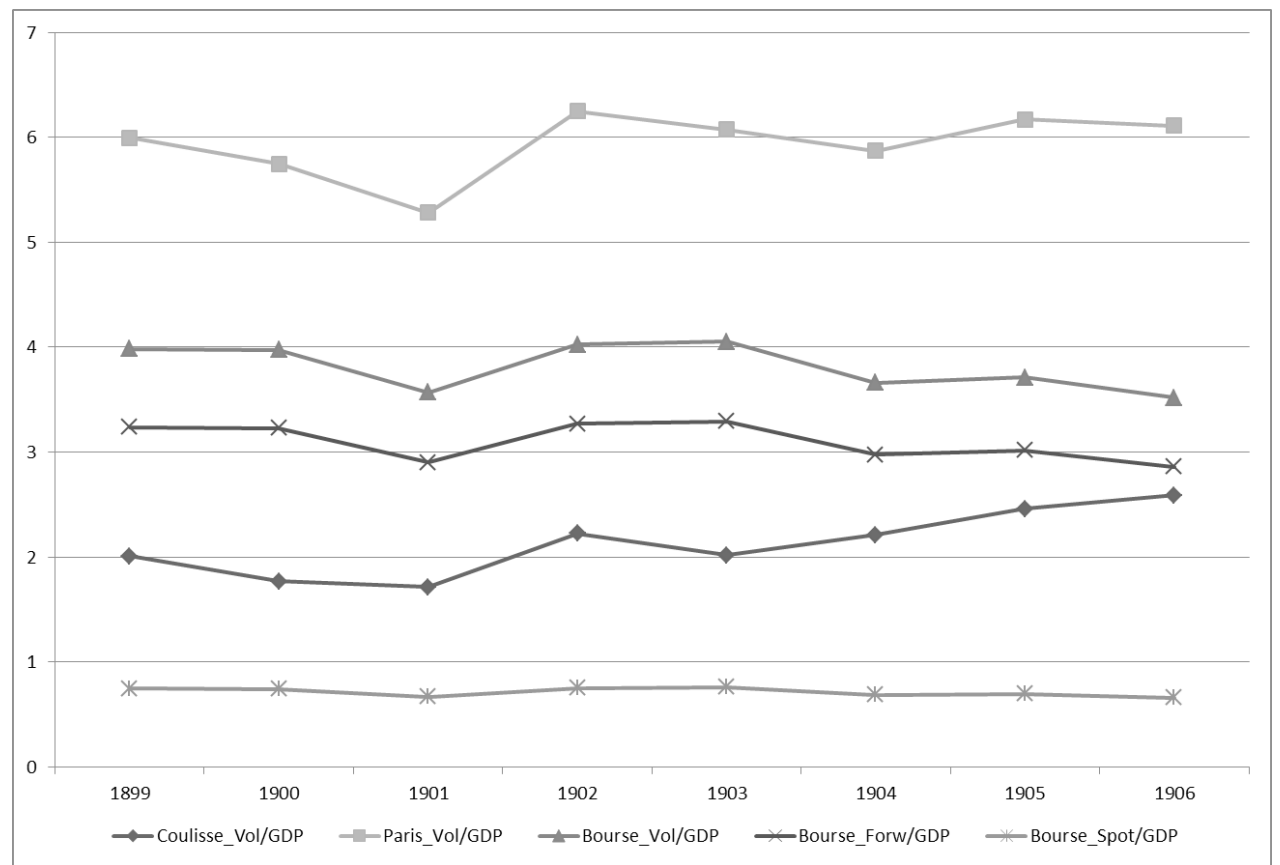

Source: see Data Appendix

Fig. 2 depicts series obtained by the interpolation of 1906 archival data with financial transaction tax data for the Paris Bourse and its OTC market over a period when the rates of taxation were constant. ${ }^{18}$ It indicates that between 1899 and 1906, the Paris financial center traded about six times the value of French GDP, with the 
overall volumes at the Bourse amounting to four times the GDP. The forward volumes corresponded to three times the GDP. By comparison, in 2006, the overall volumes traded at the Paris Stock Exchange were of the same magnitude (four times the French GDP, counting on both sides), with the derivatives only accounting for $60 \%$ of the overall traded volumes ${ }^{19}$.

\section{Institutional Threats to Forward Trading}

The official brokers had unlimited liability for the completion of the transactions they performed under their legal monopoly. Despite the ban on forward operations, they expanded this unlimited liability to the latter. Meeting regulators' expectations and containing competition from the OTC market explain this decision. However, the discrepancy between the legal framework and the actual business practices attributed a pivotal role to the judges. The Bourse's president described this situation as a 'Sword of Damocles.' ${ }^{20}$

\subsection{The legal ban on forward operations}

The ban on forward operations appeared in the decree (September 24, 1724) that had instituted the Paris Bourse, in the aftermath of the collapse of Law's system. For similar reasons - restraining 'speculation' and the disorders it caused among the Parisian business community -, the ban was re-enacted by decree on October 2, 1786. Forward operations were deemed fictitious, and hence illegal, unless the transactions were settled within two months by the actual delivery of the securities that the seller was obliged to possess when the contract was made. During the French Revolution, manipulations were so severe that the Bourse was officially closed and forward traders could be fined, pilloried and jailed.

The Napoleonic codes did not directly address forward operations. The preliminary works to the 1804 Civil Code indicate that the lawmakers were still marked by the financial disorders of the Revolution. Therefore, anti-speculative views prevailed, as stated in the Law of October 12, 1795 on the police of the Bourse and in the decree of June 16, 1802 on exchanges. ${ }^{21}$ Risk could be the object of a contract (e.g., an insurance contract), but the Civil Code did not recognize uncertainty as a 'serious cause' for contracting. Uncertainty-based contracts - and forward contracts were deemed such - were therefore equated with bets and gambling was not given any legal protection (art. 1965, on the so-called 'exception de jeu [the bet exception]').

The 1805 financial crisis and economic downturn had caused the default of at least 10 stockbrokers and hence increased government mistrust. Consequently, the draft of Commercial Code was revised, in order to 'moralize' finance through specific rules for stockbrokers. ${ }^{22}$ Yet the 1807 Code of Commerce only devotes 17 articles to them and three to the organization of stock exchanges. If strictly interpreted by judges, these rules would have prevented stockbrokers from carrying out forward operations without the prior deposit of securities and cash. For instance article 85, paragraph 3 prohibited them from granting credit to their clients. Most importantly, there was no specific rule in the Code on securities trading. Article 90 only mentioned that securities trading would be regulated by pending governmental regulation. Precisely because of the issue of forwarding operations, this regulation was only passed in 1890, after their legalization. The silence of the law had two crucial consequences: on the one hand, judges were free to base their decisions on the prohibitions decreed by the Ancien Régime; on the other hand, the organization of trading activities relied on the official stockbrokers, without their rules having been recognized by the government as required by law. Courts judged them as private rules. 
In 1809, Reynier's infamous bankruptcy discredited the Bourse and its intermediaries in general: his forward operations on French public bonds amounted to 1,305,000 francs (about 2\% of all the public debt), forcing 19 stockbrokers out of business. This affair profoundly shaped the rules on financial transactions, which were added in the 1810 Penal code: ${ }^{23}$ articles 419,421 and 422 equated the forward sale of public bonds without previous deposit with forbidden betting, punishable by a custodial sentence and a heavy fine. Until the 1885 law, the legal framework remained unchanged: it was pretty hostile to forward operations, with room for judicial interpretations according to the circumstances, in particular to tame the market through its official intermediaries. $^{24}$

\subsection{The contested monopoly of the agents de change}

The financial intermediation from the Ancien Régime survived the French revolution as a contested monopoly granted by the government to a guild of appointed merchants. The Le Chapelier Law (June 14-17, 1791) banned guilds and unions, and proclaimed free enterprise. Consequently, brokerage was liberalized. But the financial disorders of the last decade of the century were so intense that the public authorities soon restored a legal monopoly, based on that of the pre-revolutionary era, for financial intermediation, as they did for other activities: ${ }^{25}$ the only persons entitled to perform financial intermediation were the agents de change, pure stockbrokers appointed by the Ministry of Finance (officiers ministériels), holders of an office. The organizational features of the system of office were restored as a governmental device of financial intermediation. ${ }^{26}$ Article 76 of the 1807 Code of Commerce broadly defined their monopoly, to cover the trading of 'public bonds and other securities that can be quoted [effets publics et autres susceptibles dêtre cotés]'. In addition to the hybrid status there was a numerus clausus: no more than 60 official stockbrokers would be entitled to organize the Bourse through a guild-like body: the Compagnie des Agents de Change, with its peer-elected governing body, the Chambre Syndicale, chaired by a president, the Syndic. The setting of the Bourse also reenacted pre-revolutionary rules and it demonstrated the agents' dual role (facilitating transactions and participating in their control): they should operate in public, in a restricted area, in the middle of the Exchange building, with the open outcry as price-discovery mechanism and fixed commissions as payment.

Each stockbroker was legally bound to engage his unlimited liability for the transactions carried out under their monopoly: the "faits de charge". Failure to fulfill this obligation exposed brokers to fraudulent bankruptcy (punishable by forced labor). The legal liability did not encompass forward operations insofar as the law did not recognize them. Nevertheless, the individual interest of each stockbroker in preserving his reputation and their collective interest in satisfying the expectations of the public authorities (market reliability), in order to keep their monopoly as large as possible, prompted the agents to extend their individual and collective guarantee to these operations: the net debts of one had to be paid by his fellows. Refusal would have opened the door to their long-time rivals: the coulissiers.

In parallel to the Bourse, informal intermediaries (coulissiers) had developed an OTC-like market (coulisse). They traded unlisted securities and performed operations forbidden by the rules of the Bourse. The coulissiers also competed in the core activity of the agents de change: forward operations on large issues of bonds (often public and/or foreign). This competition enhanced the institutionalization of the Bourse through a process of differentiation from the OTC market, leading to a beneficial complementarity. ${ }^{27}$ Therefore, legal proceedings against the coulissiers were exceptional, even though the latter always lost (e.g., the highly publicized 1859 trial). The government informally favored retaliation solely in the case of durable bearish speculation by the coulissiers on public bonds, while it appreciated their activity when they contributed to the success of public 
bond issues and the international strength of the financial center. ${ }^{28}$ Agents only sued when the coulissiers' market share threatened their profitability. On these occasions, the legal status of forward operations was part of the jurisdictional dispute: since the legal bans only mentioned the agents, the coulissiers argued that forward operations were only prohibited for them because of their specific legal status. On the contrary, the agents promoted the largest possible definition of their monopoly, including all securities, whether traded on spot or through forward operations. This exposed them to greater potential losses.

To extend the guarantees to clients and expand the business, the agents de change organized partnerships with wealthy associates. Because only an individual could be holder of an office, the legality of the partnerships and the nature of the associates' liability were also matters of legal debate. In 1862, after a long and disputed process of legal drafting, the agents obtained from the government the introduction into the French Commercial Code of a specific corporate form exclusively for their partnerships, based on the société en commandite (art 75 , modified by the law of July $2^{\text {nd }} 1862$ ): each agent became the only unlimited liable general partner while the other associates in the firm would act as limited partners.

\subsection{The dynamics of the jurisprudence}

The discrepancy between the legal framework and business practices endowed judges with a role of pivotal importance. The stockbrokers adapted their practices to the judges' expectations and the lobbying and litigations of the former influenced the latter. Regime changes also catalyzed the jurisprudence of forward operations. By demonstrating their legitimism to each new ruler who badly needed to tap into the domestic capital market, the agents gained recognition of the business they performed. Moreover, individual savings gradually became dependent on financial markets, if not invested in often unaffordable real-estate. Therefore, financial turmoil could affect the support of the bourgeois for the rulers, giving them good reason to consider financial regulation as a matter of 'public order'.

Until 1805, the courts of justice refused to uphold forward operations, but the financial turmoil of that year provoked a first reversal in the jurisprudence. To make the business community pay for the disorder its speculation had provoked, and drawing on the 1786 decree, the judges upheld forward contracts, even those without the actual delivery of the securities, provided their duration was no longer than two months and provided the agents had operated in a suitable manner (including a discount clause in the contract). ${ }^{29}$ This jurisprudence, which was quite favorable to the agents, lasted less than two decades: incapable of containing massive speculation on the Spanish debt, they suffered a complete jurisprudential reversal following the political hardening of the Restauration.

In 1823, five of them went bankrupt. In an official extraordinary hearing chaired by the Minister of Justice, the Court of Appeal of Paris fixed the new jurisprudence (August 9, 1823): the agent Perdonnet lost against Forbin-Janson, his aristocratic and rich debtor. Although the court explicitly recognized the felony of the latter, it refused to uphold the forward contracts. The verdict was confirmed by the Cour de Cassation, the highest French Court (August 11, 1824). Neither the 1824 petition signed by prominent Parisian bankers, nor the plea by the banker and Member of the Parliament Casimir Périer (February 27, 1826) could modify it. Under the July Monarchy, the jurisprudence softened. The judges maintained the prohibition of forward operations without delivery, but they were more willing to uphold those settled by the actual delivery of the securities. The courts then introduced a further distinction, drawing on article 422 of the Penal Code, between forward sales, prohibited without prior deposit of securities even if settled by their delivery, and forward purchases without the prior deposit of cash. The latter were deemed licit, as long as the stockbrokers 
could prove the 'seriousness of the transaction'. They should demonstrate their bona fide in the appreciation of their clients' 'morality' and solvency, based on their social status, lifestyle and other proxies for wealth such as publicly-known real estate. This incremental change was abruptly stopped by the default of four agents, which in 1842 resulted in stockbroker Bagieu's criminal conviction for betting on public bonds.

After the 1848 Revolution, the courts decided that the Ancien Régime's ban was no longer applicable and developed less stringent interpretations of the current laws. For instance, payments and deliveries related to trading were exempt from the prohibition on stockbrokers from granting credit to their clients stated in art. 85, $\$ 3$ of the Commercial Code. Forward operations were upholdable if deemed 'serious', independently from the actual delivery of securities. Evidence accepted by the judges still included the notability of the client (social status and real-estate property) relative to the value of the transactions, and the agents' due diligence with respect to Bourse rules. This change was also eased by the replacement of judge Séguier as first President of the Paris Court (1810-48), notoriously opposed to financial practices he considered speculative, by judge Troplong (1848-52), a close ally of Louis-Napoléon Bonaparte. According to Troplong, financial activities should be promoted, given their contribution to the development of new industries, especially railways. ${ }^{30}$ In 1860 and 1868, the Cour de Cassation (under the Troplong presidency) endorsed this jurisprudence.

In the early days of the Third Republic, most judges abandoned the valuation of the client's notability to focus exclusively on compliance with the rules of the Bourse. Nonetheless, when public bonds were at stake or if the case turned into a scandal, some judges still equated forward selling with gambling. In the aftermath of the 1882 crash, this minority view reversed the jurisprudence: many clients were unable to pay but others took advantage of the exception de jeu to repudiate their losses.

\section{Making Forward Trading Legitimate}

To cope with the 'sword of Damocles' represented by the institutional threats on forward operations, the agents first tried to make them legitimate, and thus upholdable by judges, as a precondition for their legalization by the legislators. To reach this goal, they developed three mutually reinforcing strategies. They gained a dominant position among the Parisian business elites, developed their market organization and advocated the legitimacy of serious business practices run by serious men in front of the judges.

\subsection{The rise of the agents' status}

The debates about speculation, and especially forward operations, gave competing dominant fractions of French society the opportunity to defend their interests and legitimate their positions. ${ }^{31}$ The Bourse made it possible to imagine or even to achieve (although infrequently) a faster rhythm of capital accumulation, compared to the intergenerational rise in notability, based on land-ownership and, to a lesser extent, on commerce or production. This does not imply that notables did not trade financial instruments, or that financiers discarded property ownership. On the contrary, deals of all kinds intermingling old families and new money soon became commonplace. ${ }^{32}$ But, notables could still exploit the hostile legal framework, punctually repudiate their losses at the Bourse and, more generally, scorn the homines novi of the finance world. Reciprocally, financiers invested in real estate to diversify their wealth and secure their social status. As Louis Bergeron ${ }^{33}$ pointed out, the French Revolution did not put money at the heart of the new social hierarchy, but private property instead. 
Over the century, the stockbrokers' status varied dramatically. In 1801, when Bonaparte decided to restore official intermediation, a quarter of the newly appointed agents had been in charge before the Revolution. Nicolas Mollien, Bonaparte's main financial advisor, deliberately favored experience, while he also compensated bankers' straw men and newcomers with political connections. ${ }^{34}$ Favoring old ties was not sufficient: among the first 115 agents, 4 committed suicide, 12 were officially dismissed, 30 were forced to resign, and 8 left for other occupations. To stabilize the group, the government granted the agents the right to designate their successors (decree of May 29, 1816), which would be first endorsed by the Chambre Syndicale, then approved by the general assembly of the Compagnie, and eventually appointed by the ministry of finance. Such a process gave the Chambre the upper hand in the selection process, it promoted peer-monitoring and it also lengthened the temporal horizon of the agents. They could build family-based strategies for the transmission of their business, rather than go bust trying to get rich too quickly.

Yet, stockbroking long remained poorly regarded, compared to the status of propriétaire or other lucrative occupations with higher standing. ${ }^{35}$ In 1824, in the midst of the Forbin-Janson vs. Perdonnet case, the Chambre added personal wealth and family credentials as recruitment criteria. Therefore, candidates were expected to bring money, connections and prestige (especially among legal professions) to the guild. In doing so, the Chambre also set the conditions for a more integrated and integrative group, composed of self-elected individuals sharing a common ethos. This was made up of dispositions (obedience and reliability) and aspirations (social climbing into high society) reflecting the agents' singular position, between the raison d'Etat and market dynamics, within a collective endeavor, which both supported and constrained them. Between 1818 and 1859 , about $25 \%$ of the agents did not last more than 5 years. Nonetheless, over the rest of the century, turnover decreased while the family transmission of business increased. ${ }^{36}$

After its considerable rise under the Second Empire and its contribution to the financing of the war indemnity to Germany, a new aristocracy of financial wealth took over the Third Republic. Most agents were not part of this aristocracy dominated by bankers, industrialists and crony politicians, but stockbrokers had become legitimate, well-established members of the bourgeoisie (Tab. 1). 
Tab. 1: Changing social characteristics of the Paris agents de change in percentage (1810-1914)

\begin{tabular}{|c|c|c|c|c|c|c|}
\hline \multicolumn{2}{|c|}{ Social stratification } & \multicolumn{5}{|c|}{ Period of nomination of the agents } \\
\hline Categories by & Categories by & $1810-$ & $1830-$ & $1850-$ & $1870-$ & $1890-$ \\
\hline Charle & Verley & 1829 & 1849 & 1869 & 1889 & 1914 \\
\hline \multirow{4}{*}{$\begin{array}{l}\text { Upper-middle } \\
\text { class }\end{array}$} & & 45,5 & 45 & 34 & 40 & 39 \\
\hline & Merchants & 18 & 25 & 11 & 19 & 4 \\
\hline & Rentiers & 4,5 & 14 & 14 & 15 & 9 \\
\hline & $\begin{array}{l}\text { Agents de } \\
\text { change }\end{array}$ & 23 & 6 & 9 & 6 & 26 \\
\hline $\begin{array}{l}\text { Legal } \\
\text { professions }\end{array}$ & $\begin{array}{l}\text { Lawyer, } \\
\text { notaries, } \\
\text { judges }\end{array}$ & 4,5 & 6 & 13 & 12 & 17 \\
\hline $\begin{array}{l}\text { Intellectual } \\
\text { professions }\end{array}$ & $\begin{array}{l}\text { Professions } \\
\text { (except legal) }\end{array}$ & 4,5 & 4 & 3 & 15 & 13 \\
\hline $\begin{array}{l}\text { Upper-middle } \\
\text { Civil servants }\end{array}$ & $\begin{array}{l}\text { Upper-middle } \\
\text { Civil servants }\end{array}$ & 14 & 10 & 8 & 4 & 9 \\
\hline \multirow{4}{*}{$\begin{array}{l}\text { Small } \\
\text { bourgeoisie or } \\
\text { working class }\end{array}$} & & 31,5 & 35 & 42 & 29 & 22 \\
\hline & $\begin{array}{l}\text { Employees, } \\
\text { low-range } \\
\text { Civil servants }\end{array}$ & 9 & 10 & 5 & 11 & 11 \\
\hline & $\begin{array}{l}\text { Boutique } \\
\text { owner }\end{array}$ & 18 & 13 & 16 & 6 & 0 \\
\hline & Other & 4,5 & 12 & 21 & 12 & 11 \\
\hline
\end{tabular}

Sources: Personal files; Charle (1987); Verley (2007). 


\subsection{The building-up of an organization}

The government of the Restauration, in need of a huge issue of public bonds, granted the Chambre Syndicale large regulatory powers and full arbitration and disciplinary powers over the stockbrokers with the decree (ordonnance) of May 29, 1816. The Chambre developed a reliable organization to cope with the threats inherent to stockbroking and to demonstrate the seriousness of the agents' business. Initially, despite its large regulatory and disciplinary powers, it had difficulty in monitoring the agents. They were willing neither to give up profit opportunities nor to hand the control of their business over to the group: in the aftermath of the 1823 crisis, six brokers defaulted. The ministry of Finance revoked the Chambre, and designated the stockbrokers who should form the new governing body. The new jurisprudence of the Perdonnet vs. Forbin Janson case was the punishment for the brokers' defaults and the Chambre's lack of due diligence in monitoring them. In making such an example, the ministry signaled that stability was not optional; it was the only way for the agents to preserve their monopoly. This triggered a rationalization of trading, clearing and settlement on the one hand, and close monitoring of the brokers by the Chambre on the other.

For each security, the first forward price of the day was established by comparing all the orders received since the close of the previous session. Then, the agents performed an open-outcry continuous auction around a pit. They standardized the types of orders, the clauses attached and the back-office procedures. ${ }^{37}$ They published a daily list of forward prices, even though the legal status of these transactions had not changed, and hence conferred more transparency. In 1844, building on the growing support of the bankers and the ministry of finance, who had considered the criminal conviction of the stockbroker Bagieu in 1842 to be detrimental to the business community at large, ${ }^{38}$ the agents obtained the informal authorization to publish the forward prices on the official list, previously devoted exclusively to spot prices.

To ensure reliability, transparency was not enough: clearing and settlement were crucial. The latter reassured the clients and its regularity was one of the best ways to demonstrate the agents' professionalism and the seriousness of their operations. From 1808 onward, the process always gave clients the possibility of actual delivery of securities. Monthly bilateral and decentralized clearing (liquidation générale) was reformed in 1808, after the Banque de France threatened to close the agents' accounts because of messy transfers and lack of controls. The Chambre then implemented the central clearing: each agent should clear his clients' accounts and then at a fixed date, all agents netted their residual balances, on a bilateral basis. By 1834, the procedure was reliable enough to be quoted in example by the Member of Parliament and former stockbroker Baillot to counter a proposition to renew and enforce the ban on forward operations; in 1836, the Banque de France agreed to combine the calendar of its monthly operations with the agents' central clearing and settlement. A decade later, the agents were confident enough in their bookkeeping and in the group they constituted to adopt multilateral clearing: from 1843 on, each of them only established his netted position vis-à-vis the others. After 1848, the clearing and settlement of the Bourse helped to convince the judges that forward operations were not gambling.

Last but not least, the common fund soon became the organizational centerpiece to cope with defaults and subsequent counterparty risk, ${ }^{39}$ demonstrate the reliability of the Bourse and cement the cohesion between agents. Created in 1818, as a sinking fund to reimburse debts collectively contracted in the event of a crash, the fund was perpetuated 4 years later. Individual contributions proportionate to each agent's turnover provided the Chambre Syndicale with discretionary resources to help distressed agents ${ }^{40}$ and to cover the losses in case of defaults. The fund was first used as a liquidity and bail-out facility, during the 1830 Revolution. It 
was indeed a powerful instrument, especially as a means to obtain political support in times of financial and political crisis. Again in 1848, the revolution provoked a deep financial crash; thanks to the common funds, the heavy losses brokers suffered were settled without losses for their clients; by absorbing huge losses, the agents could gain and maintain the support of the new regime and benefit from the judges' benevolence. The common fund acted not only as a central counterparty, but also as the cornerstone of the voluntary collective guarantee of the Compagnie des Agents de change on the Bourse's transactions. The wealth of the agents and their families as well as their borrowing capacity could be mobilized through the fund, as happened in many crises.

In the 1830s, the Chambre Syndicale started the regular biannual control of brokers' standardized accounting. It also carried out one-off controls when the forward positions of a broker observed around the pit were deemed dangerous. As an arbitrator acting as a commercial court for exchange contracts, the Chambre systematically gave satisfaction to the clients against brokers when the disputed operations did not exactly respect the rules of the Bourse. This was a way to avoid lawsuits that could be lost in the courts. As a disciplinary body, the Chambre took care of the orderly functioning of the market by punishing stockbrokers who did not abide by the trading rules.

Despite fierce debate among agents, not always willing to support the monetary and regulatory burdens, the Chambre Syndicale developed these kinds of interventions. They were a powerful means of legitimation, especially in time of crisis. Despite some adjustments, like the introduction of bi-monthly settlement and delivery for the more volatile securities to reduce counterparty risk, this setting remained stable until the beginning of the 1890s: after the 1885 legalization, the securities law promised by article 90 of the 1807 Commercial Code was passed and the internal rules of the Bourse subsequently reformed.

\subsection{The making of the jurisprudence}

Over the first decades of the $19^{\text {th }}$ century, the Chambre tried to align the jurisprudence, its internal rules and the agents' actual business practices, incrementally adjusting each one to fit the others. 'Sirs, it is of the utmost importance for the Compagnie', argued the Syndic in 1833, 'to see a wise and enlightened jurisprudence being formed on all the topics related to our profession, in order to replace, as far as possible, the rules promised to us by Article 90 of the Commercial Code'. ${ }^{41}$

To this end, the Chambre centralized the litigation opposing the agents and their clients, by imposing its formal authorization for any legal action taken by an agent against his clients. Starting in 1820, the measure was opposed by most agents, since it could be detrimental to their individual interests, but as they learned through the Forbin-Janson scandal, such selection could also protect the group from bad publicity and harsh reversals. Most importantly, it only brought before the courts those cases that were favorable to and winnable for the agents. After 1823, "the Chambre Syndicale always took the greatest care that judges only had to rule on indisputably clear-cut cases in favor of the official stockbrokers" 42 Because of its position and its constant exchanges with legal scholars, lawyers, judges and policy-makers, the governing body of the guild was in a better position than its members to appreciate their chances of winning cases. If not, agents were 'invited' (an understatement) to settle their disputes either bilaterally or with the Chambre as arbitrator. By these means, the Chambre also put pressure on recalcitrant agents to select their clients and give them credit according to their notability and wealth (following the judges' expectations). 
In exchange, the agents could count on being advised and defended by leading lawyers, paid by the common fund as long their cases were of common interest for the group. Moreover, the Chambre archived all the documents related to financial law and jurisprudence, as well as the notes and files exchanged with lawyers, judges and politicians. This cumulative knowledge and experience helped to support cases, whether brought to court or privately settled.

The Chambre also tried, as far as possible, to keep the legal disputes within the jurisdiction of the capital. Provincial courts and judges were generally less favorable to brokers, as in 1882. In Paris, judges were more familiar with stock-exchange transactions and more easily lobbied. Members of the Chambre frequently paid social visits to judges. Moreover, after the Revolution of July 1830, former legal counsels of the Chambre were appointed to the "most prestigious positions in the courts of the capital" ${ }^{43}$ Last but not least, agents and judges rubbed shoulders professionally and socially. As the agents' status rose due to its recruitment policy, the Chambre Syndicale could also count on the brokers' individual (family) connections and their ascending collective prestige.

The effectiveness of this tactic can be appreciated by comparing the decisions obtained by the agents with those obtained by the coulissiers when suing clients refusing to pay for their failed forward operations. The analysis of 150 decisions indexed by legal scholar Edouard Badon-Pascal between 1857 and 1877 clearly confirms the judges' bias in favor of the agents. ${ }^{44}$ The 1866 crisis also illustrates the power gained by the guild to prevent legal actions. 7 agents were in distress, 5 had been forced to sell their businesses, mainly because of faithless clients. ${ }^{45}$ The Minister for Finance and banker Achille Fould protected the Compagnie from regulatory backlash by setting up a commission, chaired by the governor of the Banque de France. This commission emphasized the liquidity provided by forward operations and the stabilization of the Bourse that would come from their legal recognition. The Syndic declared that 'the report matches our views and desires so well that it could not have been better for us if the most enlightened of our legal advisors had drafted it. ${ }^{46}$ In parallel, the imperial prosecutor hampered the cases brought to the courts against insolvent agents, and judges of the Paris courts 'showed a kindness and zeal in rejecting demands for declarations of bankruptcy, which could have made people question their impartiality. ${ }^{47}$ Obtaining a four-month moratorium, the Chambre privately settled most of the disputes with insolvent agents' creditors and debtors.

\section{The Legalization of Forward Operations}

The 1882 crash ravaged the French stock exchanges, after a decade of numerous large issues (to pay the war indemnity to Germany and later to fund infrastructures), supported by the development of banks draining their customers' money from throughout the country. The Union Générale, founded in 1878 in Lyon, fearlessly competed with the main financial institutions in France, especially the house of Rothschild, and quickly became a systemic financial institution with a network of interlocking banks. ${ }^{48}$ To sell securities and obtain deposits, it successfully targeted ultramontane and Catholic conservatives through anti-Semitic and nationalistic arguments. This social group was particularly frustrated by the empowerment of the Third Republic and considered the Union Générale as a vehicle of political revenge. The competition was fierce, bribed newspapers fueled the bullish market and attracted many lay people. It became ever more difficult for the agents to refuse the execution of all the forward orders that professional clients transmitted. Once again, they accused the stockbrokers and their monopoly of hindering the growth of the market. ${ }^{49}$ 
In January 1882, after frauds and market manipulations, the Union Générale went bankrupt, triggering the most severe crash ever in Paris. ${ }^{50}$ Investors of all kinds were unable or unwilling to pay; 14 out of 60 agents became insolvent. The losses amounted 140 million francs ( $0.6 \%$ of French GDP in 1881). The common fund could not absorb such a sum but the agents raised 60 million francs among their partners and relatives, reimbursed by November 1882, while the Chambre contracted an 80 million franc loan from the Banque de France on behalf of the guild, reimbursed in a few weeks. Six agents reimbursed their debts by the beginning of February; of the eight others, five were insolvent mainly because of Union Générale-related debts. Nonetheless, the Compagnie overcame the liquidity crisis, met their obligations and no clients suffered any losses due to defaulting agents. In 1882, the Chambre authorized the agents to sue 151 clients to demonstrate their bad faith. But judges, particularly in regional courts, often ruled against the prevailing tolerant jurisprudence, in an uncoordinated reaction to the collapse of the stock market. Judges made null and void forward contracts for 117 million francs, i.e., $84 \%$ of the agents' total losses. ${ }^{51}$

The crash of 1882 and its aftermath constituted a critical moment, offering the Compagnie and the Paris Chamber of Commerce, together with legal professionals, economists and politicians in tune with financiers, the opportunity to push decisively for the legal recognition of forward operations. On the one hand, it was clear that forward trading was crucial for liquidity and thus for the development of the market; on the other hand, the legal status of forward operations was for many investors an incentive to trade without risk, since the jurisprudence was not a sufficient threat for faithless clients. It was no longer possible to leave the liabilities of forward contracts exclusively on the agents' shoulders.

A few days after the crash, the Member of Parliament Alfred Naquet proposed the full legalization of forward contracts. ${ }^{52}$ The Chamber of Commerce immediately endorsed Naquet's proposal. ${ }^{53}$ The Minister of Justice Gustave Humbert set up an extra-parliamentary commission 'to examine the modifications to be introduced into the legislation relating to the companies and the trading of securities' (decree of February 14, 1882). Among its 17 members, the agents de change were represented by Syndic Moreau, their colleague Lecomte, and a former agent, Girod, who was at that time director of the Comptoir d'Escompte, a prominent French bank. The lawyer and senator Bozerian chaired the commission and the Chambre immediately appointed him as counsel. ${ }^{54}$ It also paid good money to a syndicate of newspapers, including Le Voltaire, which published Naquet's op-eds, to influence public opinion. ${ }^{55}$ In June, the government transmitted the extra-parliamentary commission's report to Parliament, with an explanatory memorandum by well-known jurist and law professor Lyon-Caen, the commission's rapporteur. ${ }^{56}$ It recommended the legalization of all forward contracts and suggested only restricting the 'exception de jeu' to transactions in which the counterparties had formally agreed in advance not to deliver the underlying securities or commodities, a contract impossible at the Bourse.

In Parliament, Naquet defended his proposal of complete legalization of forward operations, drawing on comparative law, an informed description of the professional practices and emerging economics, including Pierre-Joseph Proudhon's analysis of speculation. ${ }^{57} \mathrm{He}$ insisted on the 'serious elements of appreciation' and 'profound calculations' required by forward operations, but argued against any protection for laypeople reckless enough to risk their money. Parliament voted for Naquet's proposal; the Senate, more conservative, only endorsed the suggestion made by the commission. The topic then lost momentum: the crash had been overcome, and Naquet abandoned the subject. He resigned from Parliament to become a senator and fight for his signature piece of legislation: the 1884 reintroduction of divorce. Nonetheless, the law was adopted without further discussion and eventually published in the Official Journal on April 8, 1885. Drawing on this law, the Cour de Cassation also clarified in the same year the agents' and coulissiers' jurisdictions: the monopoly of the 
former would be limited to listed securities, while the coulissiers gained the right to trade the others. However, this dispute would only be settled by the fiscal upholding of the agents' monopoly in 1898. Again in 1898, the Cour de Cassation eventually ruled against the 'exception de jeu', even when parties had a priori agreed not to deliver anything, a type of transaction frequent among coulissiers.

The 1885 law definitely reallocated the risk inherent to forward operations, shifting it from the stockbrokers to their clients. It paved the way for a new stream of financial regulation: securities law ('droit boursier'). ${ }^{58}$ In 1890 , the government passed the decree on securities trading announced in the 1807 Commercial Code and two years later, it approved the agents' revised rulebook. In other words, the agents' private arrangement was given legal force. This institutional setting allowed for further regulatory changes, crowned by the reforms of the French financial markets in $1898 .^{59}$

\section{Conclusion}

This paper documents the fact that at the turn of the $20^{\text {th }}$ century, the Paris Bourse was a very liquid market, contrary to the expectations of 'law and finance' literature. Overall traded volumes amounted to four times the French GDP, a ratio similar to the Paris Stock Exchange at the turn of the $21^{\text {st }}$ century. These volumes were mainly due to forward trading, which was three times as large as French GDP. Taken together, the Paris Bourse and the OTC market traded more than six times the GDP.

Throughout the $19^{\text {th }}$ century, the Bourse had been primarily a forward market, despite a ban on these operations until their legalization in 1885. Through private contracting and collective actions, the official Paris stockbrokers played a key role in legitimizing and eventually legalizing these operations. Because of the ban on forward operations, the liabilities linked to their contested monopoly and the jurisprudence, the agents de change sought to organize the fair ordering of trading through social control, institutional innovations, and legal strategies.

Jurisprudence appears to have been adaptive enough to support the development of the market. Nonetheless, the 1882 crisis showed the limits of market regulation centered exclusively on supervising the behavior of brokers. Without legalizing forward transactions, the only way to stabilize the market would have been to sacrifice liquidity.

The 1885 act paved the way for the 1890 securities law and thus opened a new field of law. This in turn allowed for further regulatory changes that culminated in the 1898 reform of the Paris financial center. This reform enhanced the transparency of financial transactions and supported the development of the number of listed securities. The reform also stabilized the Bourse by effectively dealing with counterparty risk and significantly decreased transaction costs. This development of securities law and its consequences on the actual functioning of the market made the 'Belle Époque' of the Paris Bourse possible. 


\section{References}

\subsection{Primary sources}

Archives de la Compagnie des Agents de change près de la Bourse de Paris (CAC), at the Centre des Archives Economiques et Financières, procès-verbaux de la Chambre Syndicale (CAC, CS), procès-verbaux des assemblées générales (CAC, AG) de la Compagnie des Agents de Change

Archives de la Chambre de Commerce de Paris (ACCP), III - 4.11 (12), file "Législation commerciale, 18781884 Marchés à terme", "Marchés à termes, marchés à livrer 1869-1916".

Archives nationales (AN), section F12, box 973

Archives parlementaires (AP). Recueil complet des débats législatifs et politiques des chambres françaises, various years.

\subsection{Bibliography}

Badon-Pascal, E. Des marchés à terme. Études légales au point de vue légal et financier. Paris: Marchal, Billard et Cie, 1877.

Badon-Pascal, E. La crise de la bourse, causes - remèdes, Paris: imprimerie Balitout, Questroy et Ce 1882.

Banner, S. Anglo-American Securities Regulation. Cultural and Political Roots, 1690-1860. Cambridge: Cambridge University Press, 1998.

Beck, T., and R. Levine. "Stock Markets, Banks, and Growth: Panel evidence." Journal of Banking \& Finance 28, no. 3 (2004): 423-442.

Beck, T., A. Demirgüç-Kunt, and R. Levine. "Law and Finance: why does legal origin matter?" Journal of comparative economics 31, no. 4 (2003): 653-675.

Bergeron, L. Les capitalistes en France. Paris: Gallimard, 1978.

Bien, D. "Property in Office under the Old Regime: The Case of the Stockbrokers." In Early Conceptions of Property, edited by Brewer, J., and S. Staves, 481-494. London: Routledge, 1995.

Bobœuf, P.-A.-F. Marchés à terme. Pétition adressée au Sénat pour rendre obligatoires les marchés à terme. Paris: Charles de Morgues Frères, 1864.

Bouvier, J. Le Krach de l'Union générale, 1878-1885. Paris: PUF, 1960.

Bozio, A. "La capitalisation boursière en France au XXe siècle." Master diss., Paris School of Economics, 2002. 1892.

Buchère, A. Traité théorique et pratique des opérations de la bourse. 3rd Edition. Paris: Chevalier-Marescq et C ${ }^{\mathrm{ie}}$,

Chambre Syndicale des Agents de Change de Paris, Mémoire de la Chambre Syndicale des agents de change présenté à M. le Ministre secrétaire d'Etat des Finances et tendant d’obtenir un règlement sur la négociation des effets publics. Paris : imprimerie de J.-B. Gros, 1843.

Charle, C. Les élites de la République. Paris: Fayard, 1987.

Courtois Fils, A. Défense de l’agiotage. Paris: typographie Hennuyer, 1879. 
Daumard, A. La bourgeoisie parisienne de 1815 à 1848. Paris: Albin Michel, 1996.

Davis, L., L. Neal, and E. White, "Deflation, the Financial Crises of the 1890s, and Stock Exchange responses." In Deflation: Current and Historical Perspectives, edited by R. Burdekin and P. Siklos, 271-296. Cambridge: Cambridge University Press, 2010.

De Goede, M. Virtue, fortune and faith: a genealogy of finance. Minneapolis: University of Minnesota Press, 2005.

Déloison, G. Traité des valeurs mobilières françaises et étrangères et des opérations de bourse. Paris: L. Larose et Forcel, 1890.

Demirgüç-Hunt, A., and V. Maksimovic. "Institutions, Financial Markets, and Firm Debt Maturity". Journal of Financial Economics 54, no. 3 (1999): 295-336.

Demirgüç-Hunt, A., and V. Maksimovic. "Law, Finance and Firm Growth". The Journal of Finance 53, no. 6 (1998): 2107-2137.

Euronext, “Factbooks 2006", February 16, 2007, Euronext website. Accessed on December 12, 2015, https://www. euronext.com/fr/reports-statistics/factbooks?archive=6_years_ago_and_before

Fenet, P.-A. Recueil complet des travaux préparatoires du Code civil. Paris: Videcoq. Vol. 14, 1836.

Hautcœur, P.-C., A. Rezaee, and A. Riva, "How to regulate a Financial Market: the impact of the 1893-1909 Regulatory Reforms on the Paris Bourse", PSE-EEP Working Paper, 2010/01, 2010.

Hautcœur P.-C., A. Riva. “The Data for Financial History (DFIH) Database”, 2016, manuscript, Paris School of Economics.

Hautcœur P.-C., A. Riva. “The Paris financial market in the nineteenth century: complementarities and competition in microstructures" Economic History Review, 65, no. 4 (2012): 1326-1353.

Hissung-Convert, N. La spéculation boursière face au droit, 1799-1914. Paris: éditions LGDJ, collection "Droit privé", 2009.

Jacquillat, B., and C. Gresse, "The Diversion of Order Flow on French Stocks from CAC to SEAQ international: a field study." European Financial Management 4, no. 2 (1998): 121-142.

Kaplan, S., and P. Minard. La France malade du corporatisme? Dix-huitième-vingtième siècles, Paris: Belin, 2004.

Kindleberger, C., Manias, Panics, and Crashes: A History of Financial Crisis, New York: Basic Books, 1978.

Lagneau-Ymonet, P. "Ferragus, une «sociologie-fiction» de la confiance." Actes de la Recherche en Sciences Sociales 169, no. 4 (2007): 94-104.

Lagneau-Ymonet, P. "Entre le marché et l'État, les agents de change. Une socio-histoire économique de l'intermédiation officielle à la bourse de Paris", PhD diss., École des hautes études en sciences sociales, Paris, 2009.

Lagneau-Ymonet, P., Rezaee, A., and Riva, A. "Nouvelles des archives. Aux sources de l'histoire sociale des professions boursières: les archives du personnel de la compagnie des agents de change de Paris." Entreprises et Histoire 74, no.1 (2014): 118-121.

Lagneau-Ymonet, P., and A. Riva. "Nouvelles des archives. Aux sources de l'histoire boursière : les archives de la compagnie des agents de change.” Entreprises et Histoire 58, no. 1 (2010): 179-182. 
Lagneau-Ymonet, P., and A. Riva. "Les opérations à terme à la Bourse de Paris au XIX siècle". In Le capitalisme au future antérieur. Crédit et spéculation en France fin XVIIIe - début XXe siècles edited by N. Levratto, and A. Stanziani. Bruxelles: Bruylant, 2011: 107-142.

Lagneau-Ymonet, P., and A. Riva. Histoire de la Bourse. Paris: La Découverte, 2012a.

Lagneau-Ymonet, P., and A. Riva. "Quand Pierre-Joseph Proudhon découvre l’ampleur de la spéculation boursière" Entreprises et histoire 67, no. 2 (2012b): 157-159.

La Porta, R., F. Lopes-de-Silanes, and A. Shleifer. “The Economic Consequences of Legal Origins.” Journal of Economic Literature 46, no. 2 (2008): 285-332.

Le Bris, D. “Les krachs boursiers en France depuis 1854.” Revue Economique 61, no. 3 (2010): 421-430.

Le Van-Lemesle, L. "La promotion de léconomie politique en France au XIX ${ }^{\text {eme }}$ siècle jusqu'à son introduction dans les facultés (1815-1881)." Revue d'histoire moderne et contemporaine 27 (April-June, 1977) : 270-294

Levasseur, E. Histoire des classes ouvrières et de l'industrie en France de 1789 à 1870. Paris: Deuxième tourisme, 1903.

Levine, R. "The legal environment, banks, and long-run economic growth." Journal of money, credit and banking 90, no. 3 (1998): 596-613.

Levine, R. "Finance and growth: theory and evidence". In Vol. 1A of Handbook of economic growth, edited by P. Aghion, and S. N. Durlauf, 865-934. Amsterdam: Elsevier, North-Holland, 2005.

Levine, R. "Law, finance, and economic growth." Journal of financial Intermediation 8, no.1 (1999): 8-35.

Levine, R., and S. Zervos, "Stock Markets, Banks, and Economic Growth." The American Economic Review 88, no. 3 (Jun., 1998): 537-558.

Locré, J.-G. La législation civile, commerciale et criminelle de la France, ou commentaire et complément des codes français. Tome 15. Paris: Treuttel et Würtz, libraires, 1828.

Michie, R. C. The London Stock Exchange: A History. Oxford: Oxford University Press, 1999.

Musacchio, A., and J. D. Turner, "Does the Law and Finance Hypothesis pass the Test of History?" Business History 55, no. 4 (2013): 524-542.

Navin, T. R., and M. V. Sears, “The Rise of a Market for Industrial Securities, 1887-1902”. Business History Review 29 (1955): 105-38.

Neal, L., and L. Davis. "The evolution of the structure and performance of the London Stock Exchange in the first global financial market, 1812-1914”. European Review of Economic History 10, no.3 (2006): 279-300.

Neymarck, A. De l'Organisation des marchés financiers en France et à l’étranger. Paris: Guillaumin, 1884.

Proudhon, P.-J. Manuel du spéculateur, Paris : Garnier frères, 1857.

Rajan, R. G., and L. Zingales. "The great reversals: the politics of financial development in the twentieth century." Journal of financial economics 69, no.1 (2003): 5-50.

Reffait, Ch. La Bourse dans le roman du second XIXe siècle, Discours romanesque et imaginaire social de la spéculation. Paris : Honoré Champion, 2007. 
Regnaud de Saint-Jean d'Angély, M. Code de commerce. Exposé des motifs des lois composant le Code de commerce. Paris, Demonville Imprimeur-Libraire, 1807.

Riva, A. "Compétition entre places financières: les bourses de Milan et de Gênes à lépoque giolittienne, 1894-1913." $\mathrm{PhD}$ diss., Université d'Orléans, 2005.

Riva, A. "Les bourses italiennes à lépoque giolittienne (1894-1913): une analyse institutionnaliste de leur organisation". Entreprises et histoire 48, no.3 (2007): 9-28.

Riva, A. "Microstructures et risque de contrepartie: les bourses de Milan et de Gênes à lépreuve de la crise de 1907." Entreprises et histoire 67, no. 2 (2012): 37-53.

Riva, A., and E. White. "Danger on the Exchange: Counterparty Risk on the Paris Stock Exchange in the XIX' Century." Explorations in Economic History 48, no.4 (2011): 478-493.

Rousseau, P. L. "Historical perspectives on financial development and economic growth." Working Paper 9333. National Bureau of Economic Research, 2002.

Rousseau, P. L., and R. Sylla. "Financial systems, economic growth, and globalization”, In Globalization in historical perspective edited by M. D. Bordo, A.M. Taylor, and J. G. Williamson, 373-416. Chicago: University of Chicago Press, 2003.

Schneiberg, M., and T. Bartley. "Organizations, Regulation, and Economic Behavior: Regulatory Dynamics and Forms from the 19th to 21st Century". Annual Review of Law and Social Science 4 (2008): 31-61.

Stanziani, A. Rules of Exchange: French Capitalism in Comparative Perspective, Eighteenth to Early Twentieth Centuries. Cambridge: Cambridge University Press, 2012.

Verley, P. “Les sociétés d’agents de change parisiens au XIX ${ }^{e}$ siècle”. Études et documents du CHEFF 1 (1989): 127-147.

Verley, P. "Les opérateurs du marché financier". In Le marché financier français au XIXe siècle. Volume 2. Aspects quantitatifs des acteurs et des instruments à la Bourse de Paris edited by G. Gallais-Hamonno, 21-86. Paris: Publications de la Sorbonne, 2007.

Vincens, E. Exposition raisonnée de la législation commerciale et examen critique du code de commerce. Vol. 1. Paris: Le Roi \& Videcocq, 1834.

Weber, M. La Bourse. Translated and edited by P. de Larminat, Paris: Allia, 2010 [1894].

White, E. N., "The Crash of 1882 and the Bailout of the Paris Bourse”. Cliometrica, 2007. 


\section{Data Appendix}

Data plotted on Fig. 1 and Fig. 2 come from the DFIH (Data for Financial History) database, based at the Paris School of Economics (for these series, credits: Angelo Riva). ${ }^{60}$

Data from Fig. 1 come from the annual reports of the Chambre Syndicale, presented to the end-of-the-year General Assembly of the Compagnie des Agents de Change. They measure transactions counted on one side. Data from Fig. 2 are obtained by the interpolation of detailed archival data for 1906 with data on the financial transaction tax (FTT). 1906 archival data ${ }^{61}$ are the base of our estimates and come from a survey by the Ministry of Finance to assess the effects of the FTT in view of a reform of its rates. The Ministry of Finance conducted a detailed survey of the accounting books of 12 stockbrokers at the beginning of 1907 . The accounting books of each broker were analyzed for a month in 1906 (the accounting books of broker A were analyzed for January, of broker B for February and so forth). The Ministry then summed up the registered transactions and multiplied by 70 (the total number of stockbrokers at that time) to obtain the total volumes traded in 1906, split into the different types of operations. As a consequence, traded volumes are counted on both sides. Moreover, the 1906 data are sensitive to the choice of the 12 brokers. Despite the mechanisms to control price-competition, ${ }^{62}$ trading activity was not equally distributed among brokers. ${ }^{63}$ Because of the close relationships between the Ministry of Finance and the Chambre Syndicale, whose members regularly checked the agents' accounts, we can assume that the Ministry selected 12 representative brokers to avoid potential bias in the estimates, as far as possible.

In 1893, the French government introduced an FTT, and each month up until 1907 it published, in the Bulletin de Statistique et Législation Comparées, the amounts paid by the operators of both the Bourse and the OTC market in Paris. It is hard to use the tax revenues to estimate traded volumes because tax rates varied according to the types of operations (repo vs. others) and securities (French public bonds vs. others). Nevertheless, the 1906 data allow for an interpolation with the FTT data over a period where the rates of the tax are kept constant. Thanks to this interpolation we obtain the estimates of the total volumes traded on both markets. By keeping constant the proportion between forward and spot transactions registered in 1906, we estimate the forward traded volumes over the period 1898-1907. Despite the potential bias of the 1906 data and the assumptions, these estimates give a good idea of the magnitude of the traded volumes. 


\section{Endnotes}

1. La Porta, Lopes-de-Silanes, and Shleifer, "The Economic Consequences of Legal Origins"; Demirgüç-Kunt and Maksimovic, "Institutions, financial markets"; Demirgüç-Kunt and Maksimovic, "Law, finance and firm growth"; and Beck and Levine "Stock markets, banks, and growth".

2. Levine, "The legal environment, banks"; and Levine, "Law, finance, and economic growth."

3. Beck, Demirgüç-Kunt and Levine, "Law and finance: why does legal origin matter?"

4. Musacchio and Turner, "Does the law and finance hypothesis pass the test of history?" 536.

5. Levine and Zervos, "Stock Markets, Banks, and Economic Growth"; Beck and Levine, "Stock markets, banks, and growth"; and Levine, "Finance and growth: theory and evidence".

6. Navin and Sears, "The Rise of a Market"; Rousseau, "Historical perspectives on financial development and economic growth"; Rousseau and Sylla, "Financial systems, economic growth"; and Neal and Davis, "The evolution of the structure and performance.

7. Kindleberger, Manias, Panics, and Crashes.

8. See for instance Rajan and Zingales, "The great reversals".

9. Lagneau-Ymonet, Riva and Rezaee, "Nouvelles des archives. Aux sources de l'histoire sociale"; and LagneauYmonet and Riva, "Nouvelles des archives. Aux sources de l'histoire boursière".

10. We present estimates of traded volumes counted on both sides to ease the comparison with Anglo-Saxon price-driven markets. On these markets, the exchange of securities between two parties gives rise to two operations: the broker of the selling client A transacts with a market-maker/specialist, as does the broker of the buying client B. In contrast, the exchange of securities between two investors gives rise to a single operation on order-driven markets like the Paris Bourse, since the broker of the selling client A transacts directly with the broker of the buying client $\mathrm{B}$ (Jacquillat and Gresse, "The diversion of order flow").

11. Lagneau-Ymonet and Riva, Histoire de la Bourse; Hautcœur and Riva, "The Paris financial market"; Riva and White, "Danger on the Exchange"; Hautcœur, Rezaee and Riva, "How to regulate a financial market"; and Bozio, "La capitalisation boursière en France".

12. Neymarck, De l'Organisation des marchés financiers; Weber, La Bourse; De Goede, Virtue, fortune and faith; Davis, Neal and White "Deflation, the financial crises of the 1890s"; Riva, "Les bourses italiennes à lépoque giolittienne"; Riva, "Compétition entre places financières"; Riva, "Microstructures et risque de contrepartie"; Michie, The London stock exchange: A history; Hissung-Convert La spéculation boursière face au droit; and Stanziani, Rules of Exchange.

13. Locré, La législation civile, commerciale et criminelle; Fenet, Recueil complet des travaux préparatoires; Boboeuf, Marchés à terme. Pétition adressée; Badon-Pascal, 1877, Des marchés à terme. Études légale; Badon-Pascal La crise de la bourse; Courtois, Défense de lagiotage; Déloison, Traité des valeurs mobilières; Buchère, Traité théorique et pratique des opérations; and Lagneau-Ymonet and Riva, "Les opérations à terme à la Bourse de Paris".

14. Riva and White, "Danger on the Exchange"; and White, "The Crash of 1882 ".

15. Banner, Anglo-American Securities Regulation, 106.

16. Vincens, Exposition raisonnée de la législation commerciale, 614.

17. See Data Appendix for details. 
18. See Data Appendix.

19. Authors' calculations on data from the Euronext-Paris Factbook, 2006.

20. CAC, MAG, 15/12/1852.

21. Locré, La législation civile, commerciale et criminelle, 165-208.

22. Regnaud de Saint-Jean d’Angély, Code de commerce.

23. AN, box F12 973.

24. Fenet, Recueil complet des travaux, 539-540.

25. Kaplan and Minard, La France malade du corporatisme; and Levasseur, Histoire des classes ouvrières.

26. Bien, "Property in Office under the Old Regime".

27. Hautcœur and Riva, "The Paris financial market”.

28. Hautcœur, Rezaee, and Riva, "How to regulate a financial market".

29. The "clause descompte" allows the buyer to transform the forward operation into a cash operation by calling for the application of the clause.

30. Hissung-Convert, La spéculation boursière face au droit, 271 and 353.

31. Charle, Les élites de la République.

32. Lagneau-Ymonet, “Ferragus, une 'sociologie-fiction' de la confiance”; and Reffait, La Bourse dans le roman.

33. Bergeron, Les capitalistes en France.

34. AN, box F12 973.

35. Daumard, La bourgeoisie parisienne.

36. Hautcœur and Riva, "The Paris financial market"; Verley, "Les opérateurs du marché financier"; Verley, "Les sociétés d’agents de change", 128; and Lagneau-Ymonet, "Entre le marché et l'État, les agents de change".

37. Among others, fast transmission of security transfer notifications to clients, asking the clients to sign up the settlement accounts, asking the clients for written confirmation of the orders, following the rules of the Bourse on the formal notices to clients about their default in delivery cash or securities and on the buy-in procedures.

38. Chambre Syndicale des Agents de Change de Paris, Mémoire de la Chambre Syndicale.

39. Riva and White, "Danger on the Exchange".

40. Often, the syndic demanded a backdated letter of resignations that allowed the Chambre to take full control of the broker's firm.

41. CAC, AG, 16/12/1833. 
44. Badon-Pascal, Des marchés à terme, 191. The archives do not mention that Badon-Pascal ever worked for the Chambre Syndicale. His publications and affiliation to the free-trade and anti-monopolist Société d'Economie Politique convinced us that his selection of cases was not a priori biased in favor of the agents. Of the 150 decisions listed, 65 relate to official stockbrokers. They won against their debtor customers in 30 cases. On the other hand, of the 85 cases involving coulissiers, the judges refused to uphold forward contracts 66 times because of the 'exception de jeu'. In other words, of the 101 decisions admitting the 'exception de jeu', one third relate to official stockbrokers, who thus lose half as often as the other intermediaries. In the same way, the agents profited from 30 of the 49 decisions rejecting the 'exception de jeu'.

45. CAC, AG, 26/12/1866.

46. CAC, AG, 26/12/1866.

47. CAC, AG, 26/12/1866.

48. White, "The Crash of 1882 ".

49. CAC, AG, 18/12/1882.

50. Le Bris, "Les krachs boursiers en France"; and Bouvier, Le krach de l'Union générale.

51. CAC, AG 29/3/1882 and 18/12/1882.

52. AP, year 1882 .

53. ACCP, III - $4.11[12]$.

54. CAC, CS, 13/05/1882.

55. CAC, CS, $15 / 6 / 1882$ and $12 / 2 / 1883$.

56. ACD, parliamentary documents, Annex 911, June 5, 1882.

57. ACD, parliamentary documents, Annex 1196, July 20, 1882; Lagneau-Ymonet and Riva, "Quand Pierre-Joseph Proudhon découvre"; Le Van-Lemesle, "La promotion de léconomie politique".

58. Hissung-Convert, La spéculation boursière face.

59. Lagneau-Ymonet, and Riva, Histoire de la Bourse; Hautcœur and Riva, "The Paris financial market"; and Hautcoeur, Rezaee and Riva, "How to regulate a financial market".

60. Hautcœur and Riva, "The Data for Financial History".

61. CAEF, box B.64.877.

62. Lagneau-Ymonet and Riva, Histoire de la Bourse.

63. Verley, "Les opérateurs du marché financier". 